\title{
Serum and urine vitamin D metabolite analysis in early preeclampsia
}

\author{
J A Tamblyn 1,2,3, C Jenkinson'2, D P Larner'2, M Hewison 1,3, * and M D Kilby 1,2,3, * \\ ${ }^{1}$ Institute of Metabolism and Systems Research (IMSR), College of Medical and Dental Sciences, University of Birmingham, Birmingham, UK \\ 2Birmingham Women's Foundation Hospital, Edgbaston, Birmingham, UK \\ ${ }^{3}$ Centre for Endocrinology, Diabetes and Metabolism, Birmingham Health Partners, Birmingham, UK \\ Correspondence should be addressed to M Hewison: m.hewison@bham.ac.uk \\ *(M Hewison and M D Kilby co-senior authors)
}

\begin{abstract}
Vitamin D deficiency is common in pregnant women and may contribute to adverse events in pregnancy such as preeclampsia (PET). To date, studies of vitamin D and PET have focused primarily on serum concentrations vitamin D, 25-hydroxyvitamin D3 (25(OH)D3) later in pregnancy. The aim here was to determine whether a more comprehensive analysis of vitamin $D$ metabolites earlier in pregnancy could provide predictors of PET. Using samples from the SCOPE pregnancy cohort, multiple vitamin D metabolites were quantified by liquid chromatography-tandem mass spectrometry in paired serum and urine prior to the onset of PET symptoms. Samples from 50 women at pregnancy week 15 were analysed, with 25 (50\%) developing PET by the end of the pregnancy and 25 continuing with uncomplicated pregnancy. Paired serum and urine from non-pregnant women $(n=9)$ of reproductive age were also used as a control. Serum concentrations of 25(OH)D3, 25(OH)D2, 1,25(OH) $)_{2} \mathrm{D} 3,24,25(\mathrm{OH})_{2} \mathrm{D} 3$ and 3-epi-25(OH)D3 were measured and showed no significant difference between women with uncomplicated pregnancies and those developing PET. As previously reported, serum $1,25(\mathrm{OH})_{2} \mathrm{D} 3$ was higher in all pregnant women (in the second trimester), but serum 25(OH)D2 was also higher compared to non-pregnant women. In urine, 25(OH)D3 and $24,25(\mathrm{OH})_{2} \mathrm{D} 3$ were quantifiable, with both metabolites demonstrating significantly lower $(P<0.05)$ concentrations of both of these metabolites in those destined to develop PET. These data indicate that analysis of urinary metabolites provides an additional insight into vitamin D and the kidney, with lower urinary $25(\mathrm{OH}) \mathrm{D} 3$ and $24,25(\mathrm{OH})_{2} \mathrm{D} 3$ excretion being an early indicator of a predisposition towards developing PET.
\end{abstract}

\author{
Key Words \\ - pregnancy \\ - preeclampsia \\ - vitamin D \\ - biomarker \\ - serum and urine
}

\section{Introduction}

Pre-eclampsia (PET) is a pregnancy-specific, multisystem syndrome with endothelial dysfunction and presenting with hypertension and pathologic renal protein excretion. Complicating up to $8 \%$ of pregnancies $(1,2,3)$, PET is associated with significant maternal and perinatal mortality and morbidity $(4,5)$. Despite recognition of PET risk factors, such as raised body mass index, ethnicity, advanced maternal age, pre-existing hypertension and/or chronic renal disease, PET often complicates otherwise uncomplicated nulliparous pregnancies with severe maternal-fetal consequences $(5,6)$.

The key predisposing event in PET is uteroplacental maldevelopment with abnormal decidual maternal spiral artery remodelling by invading fetal extravillous trophoblast cells in the late first and second trimester. This often precedes the onset of clinical disease, which
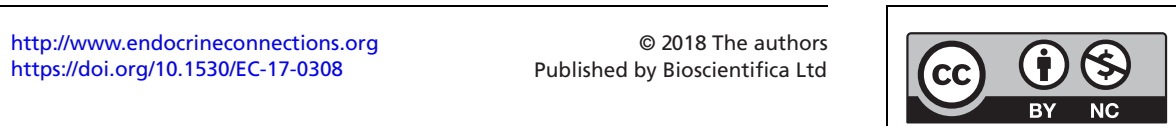

This work is licensed under a Creative Commons Attribution-NonCommercial 4.0 International License. 
later ensues secondary to tissue hypoxia, oxidative stress and release of anti-angiogenic and pro-inflammatory factors into the maternal circulation, which result in generalised systemic endothelial dysfunction (7). Consequently, there has been considerable research interest in the identification of 'early biomarkers' of PET, including anti-angiogenic factors, hormones, adhesion molecules, placental perfusion measures and vasodilators such as placental soluble fms-like tyrosine kinase (sFlt-1), soluble endoglin (sEng), maternal spiral artery resistance, pulsatility index and placental growth factor (PlGF) $(8,9$, $10,11)$. To date, systematic analysis of the efficacy of these biomarkers has been relatively inconsistent with high intra-study heterogeneity $(10,12)$.

The kidney is a key organ affected by PET. In response to normal pregnancy, significant renal adaptations ensue, including marked glomerular hyperfiltration and increased effective renal plasma flow. In PET, these functional changes differ with a significantly lower glomerular filtration rate and progressive glomerular injury $(13,14,15)$, as evidenced by the development of significant proteinuria. Potential pre-clinical markers of renal injury, including urinary podocytes, podocytespecific proteinuria nephrin and urinary albumin are now also being sought $(16,17)$. The kidneys are also the major site for vitamin D metabolism, expressing the 25-hydroxyvitamin D3 $1 \alpha$-hydroxylase (1 $\alpha$-hydroxylase) enzyme that synthesises 1,25-dihydroxyvitamin D3 $\left(1,25(\mathrm{OH})_{2} \mathrm{D} 3\right)$ from precursor 25-hydroxyvitamin D3 (25(OH)D3), as well as 25-hydroxyvitamin D-24hydroxylase (24-hydroxylase) and the vitamin $\mathrm{D}$ receptor (VDR) $(18,19)$. In uncomplicated pregnancy, significant changes in vitamin $\mathrm{D}$ physiology arise, with a surge in maternal serum $1,25(\mathrm{OH})_{2} \mathrm{D} 3$ from the first trimester (20). During pregnancy $1,25(\mathrm{OH})_{2} \mathrm{D} 3$ is also synthesised by the human placenta and decidua via localised expression of $1 \alpha$-hydroxylase, which is greatest in the first and second trimester. Coincident expression of placental VDR, 24-hydroxylase, vitamin D-binding protein and vitamin D-25-hydroxylase, suggest an autocrine/paracrine role for $1,25(\mathrm{OH})_{2} \mathrm{D} 3$ in the placenta $(21,22,23,24,25)$. The role of vitamin $\mathrm{D}$ inactivation and renal clearance in pregnancy are to be defined.

Vitamin D deficiency, defined as a serum 25(OH)D3 $<50 \mathrm{nM}$, is highly prevalent in pregnant women $(26,27)$, and recent studies have reported association between maternal serum 25(OH)D3 levels and PET $(28,29,30,31$, $32)$. A recent systematic review and meta-analysis, which included 11 observational studies, found a significant inverse relationship between maternal 25(OH)D3 and PET

$$
\text { http://www.endocrineconnections.org }
$$

risk in 5 of these studies. Meta-analyses similarly suggested an inverse relationship between maternal 25(OH)D3 and PET risk, but could not prove causality $(33,34)$. This heterogeneity reflects our limited understanding of the effects of vitamin D during pregnancy at the cellular level and suggests that measurement of serum $25(\mathrm{OH}) \mathrm{D} 3$ alone may be too simplistic. Other vitamin D metabolites such as $1,25(\mathrm{OH})_{2} \mathrm{D} 3(35)$, 3-epi-25(OH) D3 (36) and 24-hydroxylated vitamin D metabolites $\left(24,25(\mathrm{OH})_{2} \mathrm{D} 3\right)$ have received recent attention, reflecting in part the significant developments in high-sensitivity analytical methods for quantification of these metabolites $(21,37)$. Preliminary studies by our group have shown that pregnant women with PET demonstrate aberrant vitamin D metabolism in the 3rd trimester (21). What remains unclear is whether dysregulation precedes PET, or is a consequence of the onset of this disorder. The principal objective of this study was to determine whether comprehensive analysis of vitamin D metabolites earlier in pregnancy could be utilised to predict PET. Clarification of this has major functional, prognostic and therapeutic implications for the management of PET.

\section{Materials and methods}

\section{Ethical approval}

Matched serum and urine samples were purchased from the SCOPE (Screening for Pregnancy Endpoints) Ireland study (Clinical Research Ethics Committee (REC) of the Cork Teaching Hospital: ECM5 (10) (05.02.08 approval)). The SCOPE study was conducted according to the Declaration of Helsinki guidelines. Appropriate Health Research Authority - West Midlands, Edgbaston REC (14/WM/1146 RG_14-194 (09.12.2016 approval)) and material transfer agreement (MTA) (15.04.2016 15-1386) approvals were acquired by the University of Birmingham (UoB) prior to shipment (June 2016). A non-pregnant female cohort was recruited at UoB (Birmingham, UK) (REC 14/WM/1146 RG_14-194 (09.12.2016 approval)). Written informed consent was obtained from all participants recruited.

\section{Sample collection}

Overall, 1768 participants who attended for antenatal care at Cork University Maternity Hospital, Cork, Ireland $(528 \mathrm{~N})$ were recruited to SCOPE (Screening for Pregnancy Endpoints) Ireland study (www.anzctr.org.au; ACTRN12607000551493) early in the 2nd trimester (March 2008-January 2011). These were collected as part

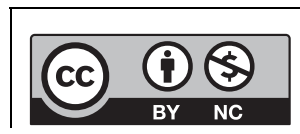

This work is licensed under a Creative Commons Attribution-NonCommercial 4.0 International License. 
of a large international pregnancy cohort study with the primary aim of developing screening tests for PET, smallfor gestational age (SGA) and spontaneous preterm birth. Six research centres participated in Auckland, Adelaide, London, Leeds, Manchester and Cork. The main inclusion criteria were a low-risk pregnancy, a singleton pregnancy $<15$ weeks of gestation and no previous pregnancy $>20$-week gestation. Specific exclusion criteria were applied: a predetermined high risk of PET, an SGA baby or spontaneous preterm birth due to an underlying medical condition (including chronic hypertension requiring antihypertensive drugs, diabetes, renal disease, systemic lupus erythematosus, antiphospholipid syndrome, sickle cell disease, HIV, previous cervical knife cone biopsy, $\geq 3$ terminations of pregnancy, $\geq 3$ miscarriages or current ruptured membranes), known major fetal anomaly or abnormal karyotype or an intervention that could modify pregnancy outcome (such as aspirin use or cervical cerclage) (38). The estimated date of delivery was calculated from a certain last menstrual period (LMP) date. Of the 1768 participants, 68 (3.8\%) developed PET.

For the current study, paired serum $(750 \mu \mathrm{L})$ and urine $(900 \mu \mathrm{L})$ was obtained at 15 -week gestation from a subset of 50 women recruited to the SCOPE study. Of these, 25 prospectively developed PET, and 25 were normotensive uncomplicated pregnancies, matched for maternal age, ethnicity and body mass index (BMI). Further detailed demographic details were obtained, including supplement and dietary intake of vitamin D, participant co-morbidities, disease course and maternofetal outcome. PET was defined as a systolic blood pressure (BP) $\geq 140 \mathrm{mmHg}$ or diastolic $\geq 90 \mathrm{mmHg}$ on $\geq 2$ occasions $4 \mathrm{~h}$ apart after 20-week gestation. Onset was either before the onset of labour or postpartum, with either proteinuria (24-h urinary protein $\geq 300 \mathrm{mg}$ or a spot urine protein: creatinine ratio $\geq 30 \mathrm{mg} / \mathrm{mmol}$ creatinine or urine dipstick protein $\geq 2$ ) or any multisystem complication of PET also present (38). Samples were anonymised by the Cork SCOPE study group, with University of Birmingham researchers blinded to the clinical outcome until after completion of the serum/urine vitamin D metabolite analysis. A healthy non-pregnant female 'control' group (NP; $n=9$ ) was also recruited at the University of Birmingham to provide whole blood and urine for comparative vitamin D metabolite analysis.

\section{Serum vitamin D metabolite quantification}

Using LC MS-MS technology, comprehensive analysis of serum vitamin D metabolites (25OHD3, 25OHD2,
3-epi-25OHD3, $1 \alpha, 25(\mathrm{OH})_{2} \mathrm{D} 3$ and $\left.24,25(\mathrm{OH})_{2} \mathrm{D} 3\right)$ was performed using previously reported methods $(21,39)$. In brief, samples were prepared for analysis by protein precipitation and supported liquid-liquid extraction (SLE). Analysis of serum was performed on a Waters ACQUITY ultra-performance liquid chromatography (UPLC) coupled to a Waters Xevo TQ-S mass spectrometer. Analysis was carried out in multiple reaction monitoring (MRM) mode, the optimised MRM transitions are described previously (32). The LC-MS/MS method has been validated previously based on US Food and Drug Administration guidelines for analysis of these metabolites (32).

\section{Urinary vitamin D metabolite quantification}

Maternal urine samples were obtained at recruitment and stored at $-80^{\circ} \mathrm{C}$ until use. Quantitative analysis of urinary de-conjugated vitamin $\mathrm{D}$ metabolites in spot urine samples was performed using a novel liquid chromatography tandem-mass spectrometry (LC-MS/MS) methodology. This was optimised from a method developed by Ogawa and coworkers, which quantified $25(\mathrm{OH}) \mathrm{D} 3$ and $24,25(\mathrm{OH})_{2} \mathrm{D} 3$ in spot urine samples obtained from healthy male participants using liquid chromatography/electrospray ionization-tandem mass spectrometry (LC/ESI-MS/MS) combined with derivatization using an ESI-enhancing reagent, 4-(4'-dimethylaminophenyl)-1,2,4-triazoline-3,5-dione (DAPTAD) (40).

Spot urine $(700 \mu \mathrm{L})$ samples were de-conjugated with $\beta$-glucuronidase 1000 units and extracted by solid phase extraction as previously described (40), hydrolysis was carried out at $55^{\circ} \mathrm{C}$. A Waters Xevo-MS coupled to an AQUITY UPLC was used for analysis following derivatisation with 4-phenyl-1,2,4-triazoline-3,5dione (PTAD) to enable the required limit of detection for analysis of these less abundant samples in urine. A Waters C18 column $(2.1 \times 50 \mathrm{~mm} 1.7 \mu \mathrm{m})$ was used for separation of metabolites. The mass spectrometry conditions were desolvation temperature $500^{\circ} \mathrm{C}$, capillary voltage $2.20 \mathrm{kV}$ and source temperature $150^{\circ} \mathrm{C}$. The mobile phase was methanol/water/0.1\% formic acid. The initial mobile phase was 50\% increasing to 98\% methanol over $2.75 \mathrm{~min}$ and held until $3 \mathrm{~min}$. The mobile phase was returned to $50 \%$ at $3.7 \mathrm{~min}$ and held until the end of the sample run at $5 \mathrm{~min}$. The flow rate was $0.5 \mathrm{~mL} / \mathrm{min}$, and sample injection volume was $20 \mu \mathrm{L}$. Optimised multiple reaction monitoring (MRM) transitions were obtained by full and daughter scan

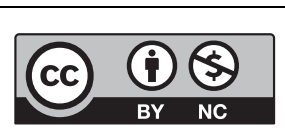

This work is licensed under a Creative Commons Attribution-NonCommercial 4.0 International License. 
runs of each compound. MRM transitions are listed in Supplementary Table 1 (see section on supplementary data given at the end of this article).

\section{Urinary creatinine correction}

Urinary creatinine correction was performed for all urine vitamin D metabolite measurements to account for intersubject variations in urinary dilution and creatinine clearance. Creatinine was measured in $10 \mu \mathrm{L}$ urine by an automated Jaffe reaction assay (R\&D Systems, KJG005). This utilises a colorimetric Jaffe reaction between creatinine and picrate acid to permit accurate and rapid quantification (41). The reaction optical density was measured using a microplate reader at a wavelength of $490 \mathrm{~nm}$. Urinary levels of vitamin D metabolites were then normalised to the sample creatinine content (ng/g of creatinine).

\section{Statistics}

Unless otherwise stated, data are shown as median values with interquartile ranges (IQR). All statistical analyses were carried out using GraphPad Prism, V7 Software Inc. Data were compared using either Mann-Whitney or KruskalWallis (non-parametric) tests based upon ranks $(P<0.05)$. Spearman's (non-parametric) correlation co-efficient was utilised to calculate $R$ value and 95\% confidence intervals $(P<0.05)$.

\section{Results}

\section{Sample description}

Overall, in the Ireland SCOPE data set, the incidence of PET was $3.8 \%$ (68/1768 pregnancies). Comparative analysis of 25 women from the 68 PET pregnancies and 25 from the 1768 healthy control pregnancies is presented in Table 1, with both maternal and fetal demographics reported. To minimise the potential seasonal effects upon vitamin D status, pregnant women were recruited across the calendar year, 21 in summer (June through October) and 29 in winter (November through May). Median gestational age (GA) at recruitment was 16 weeks (15.0-16 week) and 15 weeks (15.0-16.0 week) for the pregnant normotensive and PET groups, respectively. The time of urine specimen collection was not uniform, with median 10:00h (range 9.00-14.00) and 12:00h (range 9.00-15.00) collection in normotensive and PET pregnant groups, respectively. Concerning dietary intake of vitamin D, 15 (10 normotensive and 5 PET women) reported intake of the recommended daily dose of vitamin D (400IU/day) pre-pregnancy. In the first trimester ( $\leq 12$ week), 12 participants (9 normotensive and 3 PET) took 400 IU vitamin D daily, of which 9 (7 normotensive and 2 PET) had continued from pre-conception.

As summarised in Table 1, of the 25 women who developed PET, the mean GA at diagnosis was 37 week (range 31-41 week). In total, 7 (28.0\%) women were diagnosed with severe PET and 6 (24.0\%) developed multi-system disease. At baseline, the mean arterial blood

Table 1 Summary of donor demographic analysis.

Maternal age, years (range)
Body mass index, median ( 25 th-75th IQR), unit
Ethnicity white Caucasian, frequency (\%)
Mean arterial blood pressure, median ( 25 th-75th IQR), unit
Vitamin D supplementation (400IU daily); pre-pregnancy total (\%), 1st trimester
total (\%)
Season at recruitment (15 weeks): summer, total (\%); winter, total (\%)
Positive smoking status at 15 week, total (\%)
Gestation at PET diagnosis, mean (range) (week)
Term PET (gestation $\geq 37$ week), frequency (\%)
Preterm PET (gestation <37 week), frequency (\%)
Severe preterm PET (gestation <34 week), frequency (\%)
Gestational age at delivery, mean ( 25 th-75th IQR) (weeks)
Fetal birthweight, median ( 25 th-75th IQR) (g)
Fetal small for gestational age, frequency (\%)
Stillbirth, frequency (\%)

\begin{tabular}{c}
\hline Control $(n=25)$ \\
\hline $30.5(24.0-38.0)$ \\
$26.2(22.9-29.2)$ \\
$25(100)$ \\
$92.7(89.3-96.7)$ \\
$10(40.0)$ \\
$9(36.0)$ \\
$10(40.0)$ \\
$15(60.0)$ \\
$2(8.0)$ \\
- \\
- \\
- \\
- \\
$41.0(40.0-41.0)$ \\
$3650(3275-4040)$ \\
$0(0)$ \\
$0(0)$
\end{tabular}

PET $(n=25)$
$31(22.0-36.0)$
$25.5(22.9-29.7)$
$25(100)$
$117.3 * * * *(113.8-124.8)$
$5(20.0)$
$3(12.0)$
$11(44.0)$
$14(56.0)$
$4(16.0 \%)$
$37(31-41)$
$14(56.0 \%)$
$11(44.0)$
$1(4.0)$
$39.0 * * *(37.0-40.0)$
$3030 * *(2580-3535)$
$3(12.0)$
$1(4.0)$

Comparison of baseline maternal-fetal clinical and disease demographics in normotensive pregnant women $(n=25)$ and those pregnant women who prospectively developed preeclampsia (PET; $n=25)$. Cases were matched for age, ethnicity and body mass index (BMI). Statistically significant variations are indicated, $* P<0.05, * * P<0.01, * * * P<0.001, * * * * P<0.0001$.

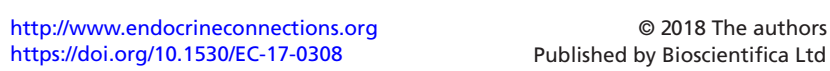




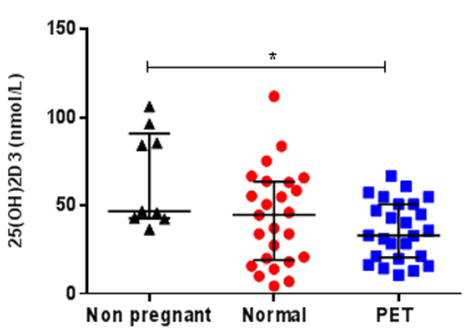

B

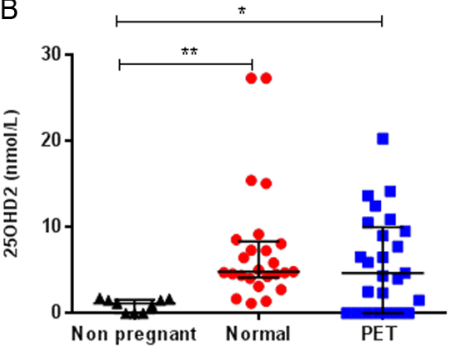

C

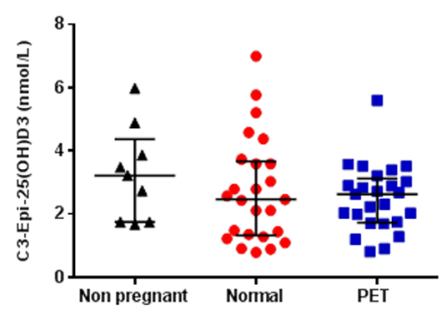

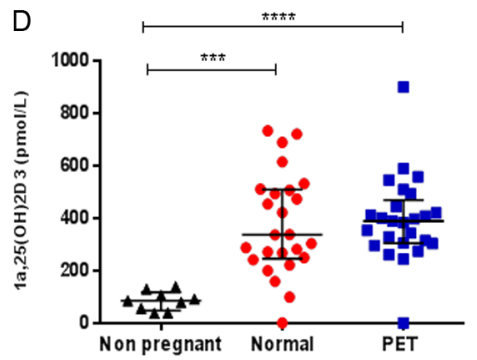

E

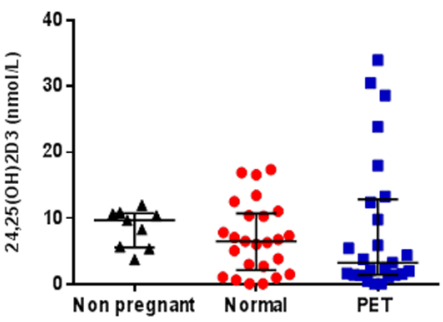

Figure 1

Serum vitamin D metabolites in non-pregnant women and pregnant women at 15-week gestation. Serum concentrations of (A) 25 -hydroxyvitamin D3 (25(OH)D3) nmol/L; (B) 25-hydroxyvitamin D2 (25(OH)D2) nmol/L; (C) 3-epi-25(OH)D3 nmol/L; (D) 1,25-dihydroxyvitamin D3 (1,25(OH) 2 D3) pmol/L;

(E) 24,25-dihydroxyvitamin D3 $\left(24,25(\mathrm{OH})_{2} \mathrm{D} 3\right) \mathrm{nmol} / \mathrm{L}$. Sample groups were non-pregnant (black; $\left.n=9\right)$, normotensive pregnancies $($ red; $n=25)$ and those who later developed pre-eclampsia (blue; $n=25$ ). Median with interquartile range are shown. Statistically significant variations are indicated, $* P<0.05$, $* * P<0.01, * * * P<0.001, * * * * P<0.0001$.

pressure (MABP) was significantly higher in the PET group comparatively $(P<0.0001)$. The mean GA at delivery was significantly earlier in those with PET $(P<0.0001)$, with the median fetal birthweight significantly lower than those in the uncomplicated cohort $(P<0.05)$. A healthy non-pregnant female group $(n=9)$ was also recruited for comparison.

\section{Serum vitamin D metabolite analysis}

In serum, five serum vitamin $\mathrm{D}$ metabolites were consistently quantifiable in both the pregnant (normotensive and PET women) and non-pregnant groups: 25(OH)D3， 25(OH)D2， 1,25(OH $)_{2} \mathrm{D} 3, \quad 24,25(\mathrm{OH})_{2} \mathrm{D} 3$, 3-epi-25(OH)D3, as summarised in Fig. 1 and Table 2.
Considering maternal 'vitamin D status', the Institute of Medicine (IOM) definition of vitamin D 'deficiency' is $25(\mathrm{OH}) \mathrm{D}<20 \mathrm{ng} / \mathrm{mL}(50 \mathrm{nM} / \mathrm{L})$ and 'insufficiency' as $25(\mathrm{OH}) \mathrm{D}>20 \mathrm{ng} / \mathrm{mL}$ but $<30 \mathrm{ng} / \mathrm{mL}(75 \mathrm{nM} / \mathrm{L})(42)$. In the normotensive pregnancy group, $14(56.0 \%)$ women were defined as vitamin D deficient and 8 (32.0\%) insufficient. In the PET group, 18 (72.0\%) were vitamin D deficient and $6(24.0 \%)$ insufficient. Although median 25(OH) D3 concentrations were lower in the PET group (median 33.1, IQR $20.5-50.8 \mathrm{nmol} / \mathrm{L}$ ) compared to the control pregnancy group $(44.7,19.1-63.5 \mathrm{nmol} / \mathrm{L})$, this was not significant $(P=0.240)$. Conversely, in the non-pregnant group, all women were sufficient $(46.8 ; 42.8-91.0 \mathrm{nmol} / \mathrm{L})$, with 25(OH)D3 levels significantly higher than values for PET $(P=0.04)$.

Table 2 Summary of serum vitamin D metabolites in pregnant women at 15-week gestation and non-pregnant controls.

\begin{tabular}{lcc} 
& & Non-pregnant $(n=9)$ (median; IQR) \\
\cline { 1 - 1 } $25(\mathrm{OH}) \mathrm{D} 3(\mathrm{nmol} / \mathrm{L})$ & & $46.8(42.8-91)$ \\
$25(\mathrm{OH}) \mathrm{D} 2(\mathrm{nmol} / \mathrm{L})$ & & $1.17(0-1.6)$ \\
$1,25(\mathrm{OH})_{2} \mathrm{D}_{3}(\mathrm{pmol} / \mathrm{L})$ & & $85.6(47.3-117.4)$ \\
$\mathrm{C} 3-\mathrm{Epi}-25(\mathrm{OH}) \mathrm{D}_{3}(\mathrm{nmol} / \mathrm{L})$ & & $3.2(1.7-4.4)$ \\
$24,25(\mathrm{OH})_{2} \mathrm{D}_{3}(\mathrm{nmol} / \mathrm{L})$ & $9.7(5.5-10.7)$ \\
\hline
\end{tabular}

\begin{tabular}{c} 
Control $(n=25)($ median; IQR) \\
\hline $44.7(19.1-63.5)$ \\
$4.8(4.2-8.3)$ \\
$336.3(245.5-508.4)$ \\
$2.5(1.3-3.7)$ \\
$6.5(2.07-10.7)$
\end{tabular}

\begin{tabular}{c} 
PET $(n=25)($ median; IQR) \\
\hline $33.1(20.5-50.8)$ \\
$4.7(0-10.0)$ \\
$388.8(304.2-468.4)$ \\
$2.6(1.7-3.1)$ \\
$3.2(1.37-12.9)$
\end{tabular}

Comparison of serum concentrations of 25-hydroxyvitamin D3 (25(OH)D3) nmol/L, 25-hydroxyvitamin D2 (25(OH)D3) nmol/L, 1,25-dihydroxyvitamin D3 $(1,25(\mathrm{OH}) 2 \mathrm{D} 3) \mathrm{pmol} / \mathrm{L}, 3-\mathrm{epi}-25(\mathrm{OH}) \mathrm{D} 3 \mathrm{nmol} / \mathrm{L}, 24,25$-dihydroxyvitamin $\mathrm{D} 3(24,25(\mathrm{OH}) 2 \mathrm{D} 3) \mathrm{nmol} / \mathrm{L}$ in non-pregnant $(n=9)$, healthy normotensive pregnancies $(n=25)$ and those who later developed pre-eclampsia (PET; $n=25)$, with median values with interquartile range interval shown.

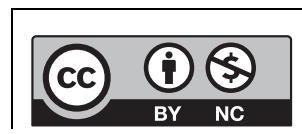

This work is licensed under a Creative Commons Attribution-NonCommercial 4.0 International License. 

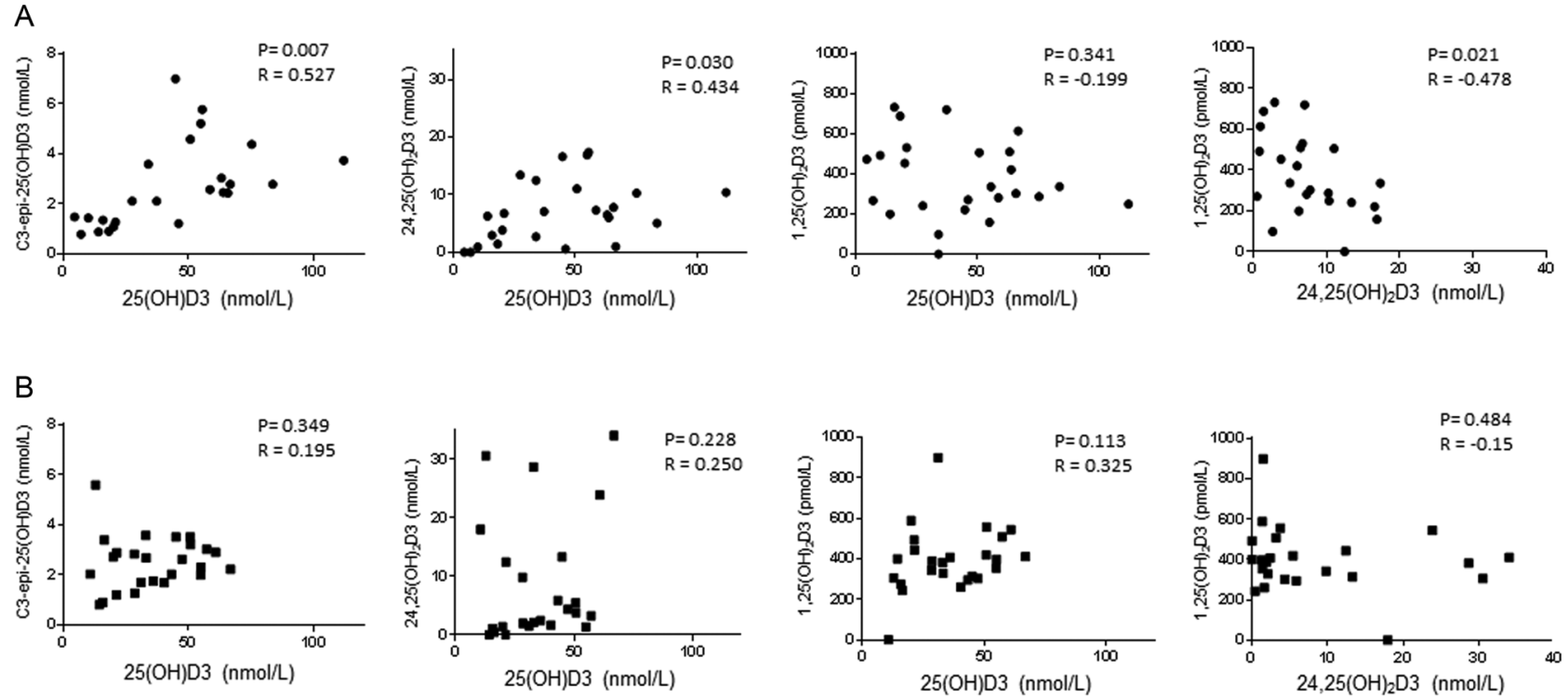

Figure 2

Effect of maternal vitamin D status (serum 25-hydroyxvitamin D3) upon other serum vitamin D metabolites at 15-week gestation; comparative analysis in healthy pregnant controls and prospective PET cases. Serum concentrations of 25-hydroxyvitamin D3 (25(OH)D3) were correlated with C3-epi-25(OH)D3 (nmol/L), 1,25-dihydroxyvitamin D3 (1,25(OH) $\left.)_{2} \mathrm{D} 3\right)(\mathrm{pmol} / \mathrm{L})$ and 24,25-dihydroxyvitamin D3 $\left(24,25(\mathrm{OH})_{2} \mathrm{D} 3\right)(\mathrm{nmol} / \mathrm{L})$ in healthy pregnant controls $(\mathrm{A})$ and prospective pre-eclampsia (PET) cases (B). Statistically significant correlations are indicated as $P$ values, with Pearson $R$ values shown.

Consistent with previous studies (38), a significant seasonal difference in serum 25(OH)D3 was observed, with higher concentrations in summer (median 50.8; IQR $39.3-59.7 \mathrm{nmol} / \mathrm{L})$ than winter $(21.3 ; 14.1-41.7 \mathrm{nmol} / \mathrm{L})$ $(P=0.0004)$. Sub-group analysis revealed that in the PET group, women pregnant during winter (24.8; $15.4-37.0 \mathrm{nmol} / \mathrm{L}$ ) had significantly lower 25(OH)D3 levels than those pregnant in summer $(50.7 ; 33.1-57.3 \mathrm{nmol} / \mathrm{L})$ $(P=0.002)$. In the normotensive group, $25(\mathrm{OH}) \mathrm{D} 3$ levels were again lower in winter $(20.8 ; 9.9-63.2 \mathrm{nmol} / \mathrm{L})$ than summer $(55.2 ; 42.0-64.6 \mathrm{nmol} / \mathrm{L})$, almost reaching significance $(P=0.05)$.
Serum concentrations of $25(\mathrm{OH}) \mathrm{D} 2$ were similar in the normotensive $(4.8 ; 4.2-8.3 \mathrm{nmol} / \mathrm{L})$ and PET $(4.7 ; 0-10.0 \mathrm{nmol} / \mathrm{L})$ groups $(P=0.352)$, and were, as anticipated, much lower than circulating 25(OH)D3 levels. No significant correlation between serum $25(\mathrm{OH}) \mathrm{D} 2$ and $25(\mathrm{OH}) \mathrm{D} 3$ in either the normotensive $(r=-0.15, P=0.48)$ or PET $(r=0.00, P>0.10)$ groups was measured. $25(\mathrm{OH}) \mathrm{D} 2$ levels were significantly lower in the non-pregnant group comparative to both the PET $(P=0.02)$ and normotensive women $(P=0.001)$. There was no significant difference in serum concentrations of 3 -epi-25(OH)D3 between the normotensive pregnant $(2.5 ; 1.3-3.7 \mathrm{nmol} / \mathrm{L})$,
A

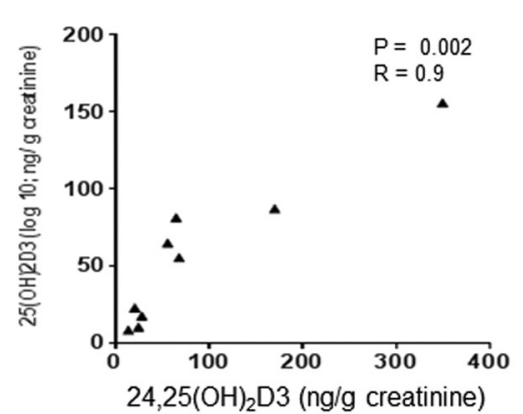

B

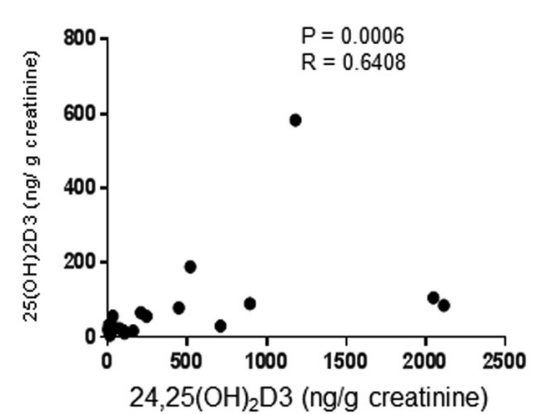

C

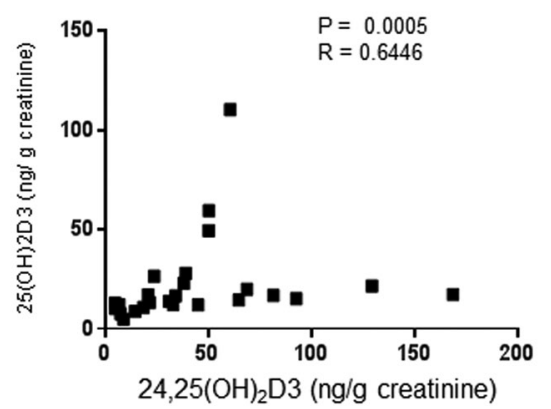

Figure 3

Relationship between excreted urinary vitamin D metabolites. Urine concentrations 25(OH)D3 were correlated with 24,25(OH) $\mathrm{D} 3$ ( $\mathrm{nmol} / \mathrm{L}$ ) in non-pregnant (A), healthy pregnant controls (B) and prospective pre-eclampsia (PET) cases (C). All nmol/L. Statistically significant correlations are indicated as $P$ values, with Pearson $R$ values shown.

$$
\begin{array}{lr}
\text { http://www.endocrineconnections.org } & \text { ○ } 2018 \text { The authors } \\
\text { https://doi.org/10.1530/EC-17-0308 } & \text { Published by Bioscientifica Ltd }
\end{array}
$$


PET (2.6; $1.7-3.1 \mathrm{nmol} / \mathrm{L})$ and non-pregnant (3.2; $1.7-4.4 \mathrm{nmol} / \mathrm{L})$ cohorts. There was a significant positive correlation between 25(OH)D3 and 3-epi-25(OH)D3 in the normotensive pregnancy group $(r=0.645, P=0.0005)$, but this was not evident in women who developed PET $(r=0.195, P=0.349)$ (Fig. 2).

Distinct from previous publications from the SCOPE study (43), $1,25(\mathrm{OH})_{2} \mathrm{D} 3$ and $24,25(\mathrm{OH}) \mathrm{D}_{2} \mathrm{D} 3$ concentrations were both quantifiable in serum samples. No significant difference in $1,25(\mathrm{OH})_{2} \mathrm{D} 3$ concentrations was measured in the PET (388.8; 304.2-468.4 pmol/L) comparative to normotensive pregnant group (336.3; 245.5-508.4 pmol/L). Consistent with previous reports (21), $1,25(\mathrm{OH})_{2} \mathrm{D} 3$ levels were significantly higher in both the PET $(P<0.0001)$ and normotensive $(P=0.0005)$ women compared to the non-pregnant group (85.6; 47.3-117.4 pmol/L).

No significant difference in serum $24,25(\mathrm{OH})_{2} \mathrm{D} 3$ was observed across the 3 groups. Similar to $1,25(\mathrm{OH})_{2} \mathrm{D} 3$, no difference in $24,25(\mathrm{OH})_{2} \mathrm{D} 3$ circulating concentrations in the PET $(3.2 ; 1.4-12.9)$ and normotensive $(6.5 ; 2.1-10.7)$ groups was measured. However, as summarised in Fig. 2, serum 25(OH)D3 levels significantly correlated with $24,25(\mathrm{OH})_{2} \mathrm{D} 3(r=0.43, P=0.03)$ in the normotensive women, whilst in those who developed PET no similar correlation $(r=0.25, \quad P=0.23) \quad$ was observed. The significant negative relationship between $24,25(\mathrm{OH})_{2} \mathrm{D} 3$ and $1,25(\mathrm{OH})_{2} \mathrm{D} 3$ measured in the normotensive group $(r=-0.48, P=0.02)$ was lost in those who developed PET $(r=-0.15, \quad P=0.484)$. No correlation between serum $25(\mathrm{OH}) \mathrm{D} 3$ and $1,25(\mathrm{OH})_{2} \mathrm{D} 3$ was observed for either group.

\section{Urinary vitamin D analysis}

Urinary $25(\mathrm{OH}) \mathrm{D} 3$ and $24,25(\mathrm{OH})_{2} \mathrm{D} 3$ were consistently quantifiable in both pregnant and non-pregnant groups. A significant positive correlation between urinary $24,25(\mathrm{OH})_{2} \mathrm{D} 3$ and $25(\mathrm{OH}) \mathrm{D} 3$ concentrations was measured across the non-pregnant $(r=0.90, P=0.002)$, normotensive $(r=0.64, P=0.0006)$ and PET groups $(r=0.65, P=0.0005)$ (Fig. 3). As summarised in Fig. 4, urinary $25(\mathrm{OH}) \mathrm{D} 3$ concentrations were significantly lower in the PET group (15.2; 12.0-22.2 ng/g creatinine) compared to normotensive pregnant women (22.9; $15.3-72.1 \mathrm{ng} / \mathrm{g}$ creatinine) $(P=0.018)$. Concentrations of urinary $24,25(\mathrm{OH})_{2} \mathrm{D} 3$ were similarly significantly reduced in those women who developed PET $(34.1 ; 16.6-62.8 \mathrm{ng} / \mathrm{g}$ creatinine) $(P=0.018)$ (Fig. 4 and Table 3$)$. Measurement of the metabolites $1,25(\mathrm{OH})_{2} \mathrm{D} 3$ and $23,25(\mathrm{OH})_{2} \mathrm{D} 3$ was

$$
\begin{array}{lr}
\text { http://www.endocrineconnections.org } & \text { ๑ } 2018 \text { The authors } \\
\text { https://doi.org/10.1530/EC-17-0308 } & \text { Published by Bioscientifica Ltd }
\end{array}
$$
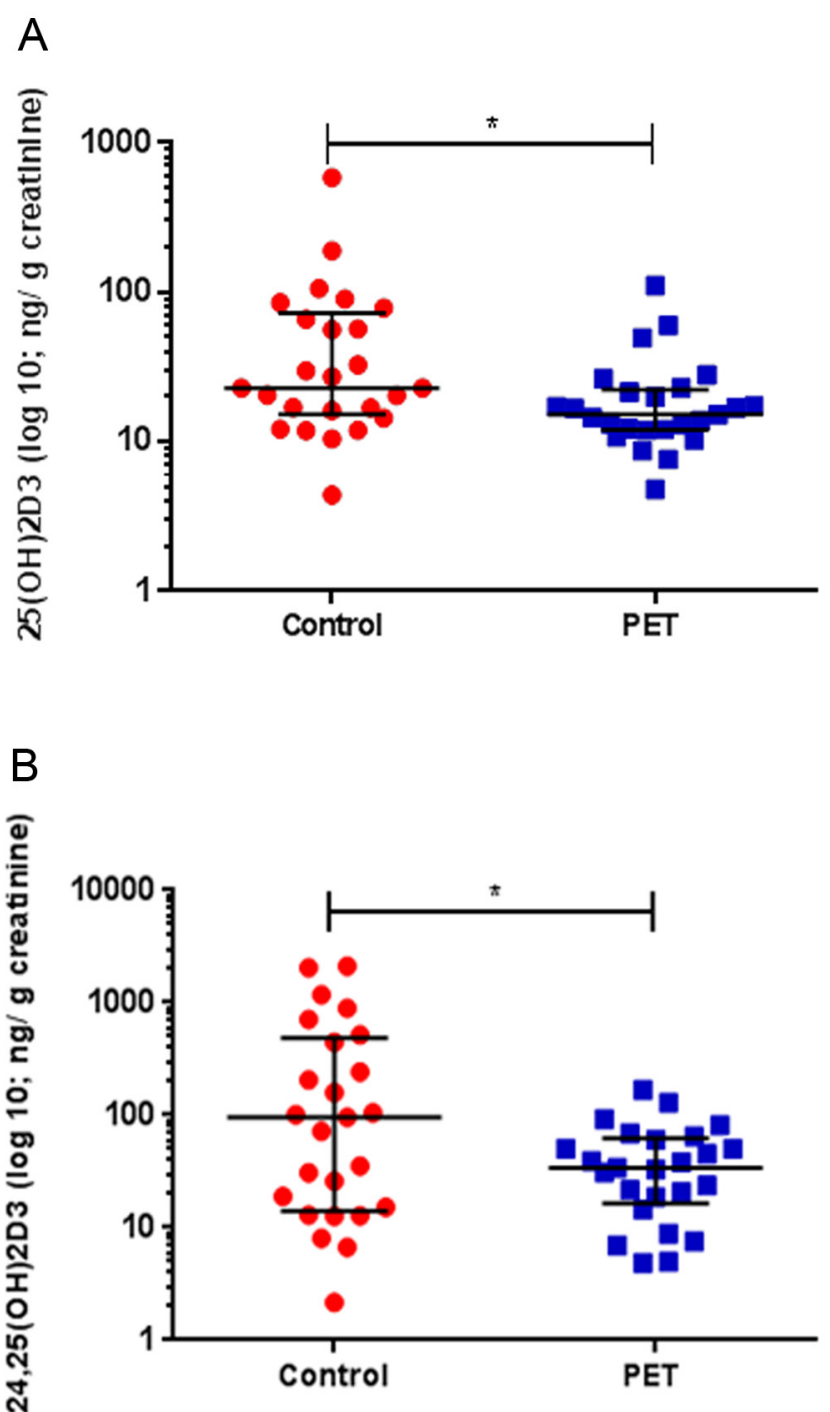

Figure 4

Urine vitamin D metabolite analysis in pregnant women at 15-week gestation. Urinary concentrations of (A) 25-hydroxyvitamin D3 $(25(\mathrm{OH})$ D3) $\mathrm{nmol} / \mathrm{L}$ and (B) 24,25-dihydroxyvitamin D3 (24,25(OH) 2 D3) nmol/L normalised for urinary creatinine ( $\mathrm{ng} / \mathrm{g}$ creatinine) for matched normotensive pregnancies (red) and those who later developed pre-eclampsia (PET; blue). Median with interquartile range values is shown. Statistically significant variations are indicated, $* P<0.05$.

incorporated into the method, but these analytes could not be quantified as concentrations were below the lower limit of detection.

\section{Discussion}

Low maternal serum vitamin D concentrations in early pregnancy have been associated with an increased risk of PET (28), but the mechanisms underlying this remain unclear. Previously, we have demonstrated that in

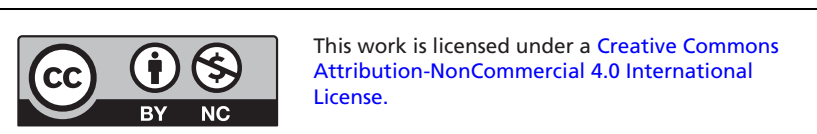


Table 3 Urinary concentrations of 25(OH)D3 nmol/L and 24,25(OH) 2 D3 nmol/L.

\begin{tabular}{|c|c|c|c|}
\hline & Non-pregnant & Control & PET \\
\hline 25(OH)D3 & $55.8(14.3-84.7)$ & $22.9(14.8-63.5)$ & $14.8(11.9-22.5)$ \\
\hline $24,25(\mathrm{OH})_{2} \mathrm{D} 3$ & $55.4(22.4-118.8)$ & $84.1(13.5-395.9)$ & $35.6(15.5-63.7)$ \\
\hline
\end{tabular}

Urinary vitamin D metabolite concentrations were normalised for urinary creatinine ( $\mathrm{ng} / \mathrm{g}$ creatinine) in non-pregnant controls $(n=9)$, normotensive pregnancies $(n=25)$ and those who later developed pre-eclampsia (PET; $n=25)$. Mean values with interquartile range are shown.

pregnant women with PET, multiple vitamin D metabolic pathways are dysregulated comparative to healthy normal pregnancy in the 3rd trimester and that this is evident for both serum and placental tissue vitamin D metabolites (21). Whilst placental vitamin D analysis offers the novel opportunity to delineate metabolism directly at the maternal-fetal interface, the clinical applications of this are limited due to the inaccessibility of this tissue throughout normal pregnancy. Given the prominent alterations in circulating vitamin D physiology across pregnancy, additional methods to ascertain vitamin D metabolism across gestation may be informative.

To advance these observations, we performed a detailed comparative analysis of serum vitamin $\mathrm{D}$ metabolites in a cohort of nulliparous 'low-risk' pregnancies at 15-week gestation of which half prospectively developed PET. To further enhance this approach, a novel urinary vitamin D metabolite quantification method was incorporated. Given the anticipated low concentrations of steroid metabolites present in urine, the analytical method employed utilised a derivatization procedure using PTAD to enhance both the sensitivity and separation of individual metabolites.

Consistent with our own data set in the West Midlands (21), vitamin D deficiency was highly prevalent in the SCOPE cohort from Ireland, particularly in winter months, with $64 \%(n=32)$ of pregnant women having $25(\mathrm{OH}) \mathrm{D} 3$ levels $<50 \mathrm{nmol} / \mathrm{L}$ at 15 -week gestation. We anticipate that this would be higher still if the cohort included pregnant women with darker skin pigmentation as demonstrated in large epidemiological studies (44). Despite current clinical recommendations for pregnant women to take daily vitamin D supplementation $(45,46)$, in this cohort only $20 \%$ of women reported taking preconception vitamin D supplementation and by the 1st trimester adherence to supplementation advice dropped to $18 \%$ of women.

In previous published work, the SCOPE whole dataset $(n=1768)$ which similarly utilised LC MS-MS to measure circulating $25(\mathrm{OH}) \mathrm{D} 3$, 3-epi-25(OH)D3 and $25(\mathrm{OH}) \mathrm{D} 2$ concluded that in women with $25(\mathrm{OH}) \mathrm{D} 3$ levels $>75 \mathrm{nM}$ a protective effect (adjusted OR: 0.64; 95\% CI: $0.43,0.96)$ upon PET plus SGA outcome is evident following adjustment for potential confounding factors, including sociodemographic status, season, ethnicity, smoking status, exercise frequency and BMI (43). In the smaller subset of the SCOPE cohort assessed here only $3(12.0 \%)$ of the pregnant cohort, none of which were in the PET group (maximum $25(\mathrm{OH}) \mathrm{D} 3=60.9 \mathrm{nmol} / \mathrm{L}$ ) had $25(\mathrm{OH}) \mathrm{D} 3$ levels $>75 \mathrm{nmol} / \mathrm{L}$. However, circulating $25(\mathrm{OH}) \mathrm{D} 3$ concentrations in those who developed PET were only statistically lower than the non-pregnant group. This may simply reflect the smaller cohort size resulting in a type 1 error, but may also be due to the heterogeneity of the PET cohort with respect to both timing of disease onset and progression. Our findings are however consistent with Powe and coworkers (47), who similarly concluded there was no significant difference in $25(\mathrm{OH}) \mathrm{D} 3$ levels in pregnant women who subsequently developed PET compared to those who remained normotensive $(27.4 \pm 1.9$ vs $28.8 \pm 0.80$; $P=0.435)$. In this particular study, DBP and free $25(\mathrm{OH}) \mathrm{D}$ levels were also assessed, with no difference between the PET and normotensive group data (47). As $25(\mathrm{OH}) \mathrm{D} 3$ reflects total body stores, the levels of this metabolite may be preserved during the early stages of PET. It appears that 25(OH)D3 alone is unlikely to be an informative vitamin D metabolite within the context of ascertaining potential risk of PET.

Although we did not observe any statistically significant differences in concentrations of serum vitamin D metabolites between the two pregnancy groups, the associations between these metabolites varied significantly. In women who developed PET, there was no positive correlation between serum $25(\mathrm{OH}) \mathrm{D} 3$ and the vitamin D catabolites 3-epi-25(OH)D3 and 24,25(OH) $)_{2} \mathrm{D} 3$. Albeit not clearly understood, alternative metabolism of vitamin D via epimerisation to 3-epi-25(OH)D3 results in the formation of 3 -epi-1,25(OH $)_{2} \mathrm{D} 3$, which binds to VDR to activate target gene transcription. Importantly, 3-epi-1,25(OH) $)_{2} \mathrm{D} 3$ appears a less potent VDR agonist than $1,25(\mathrm{OH})_{2} \mathrm{D} 3$, which may have physiological consequences (48). In normal pregnancy, 3-epi-25(OH) ${ }_{2} \mathrm{D} 3$ appears directly linked to 25(OH)D3 concentrations (43); however, in the SCOPE cohort this relationship was lost only in those women who developed PET.

$$
\text { http://www.endocrineconnections.org }
$$

This work is licensed under a Creative Commons Attribution-NonCommercial 4.0 International License. 
A trend towards elevated serum $1,25(\mathrm{OH})_{2} \mathrm{D} 3$ was also observed in the PET samples. This may reflect a compensatory response to lower $25(\mathrm{OH}) \mathrm{D} 3$, but may also contribute to depletion of $25(\mathrm{OH}) \mathrm{D} 3$. Healthy pregnancy is characterised by a drive towards $1,25(\mathrm{OH})_{2} \mathrm{D} 3$ production (21), and there is also evidence of increased upregulation of CYP27B1 (1 $\alpha$-hydroxylase) and CYP24A1

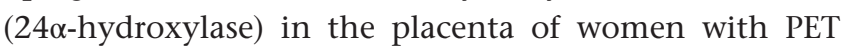
(4). Increased metabolism of $25(\mathrm{OH}) \mathrm{D} 3$ to $1,25(\mathrm{OH})_{2} \mathrm{D} 3$ may also be secondary to decreased total serum calcium concentrations, which arise during normal human pregnancy (49). Within the context of PET, serum calcium concentrations are usually significantly reduced (50). A prospective study measuring the urine calcium/ creatinine $(\mathrm{Ca}: \mathrm{Cr}$ ) clearance ratio also found women with PET excrete significantly less calcium $(n=60)$ compared to normotensive controls (51). In the current study, this may account for enhanced renal 25(OH)D3 re-uptake, limiting metabolite excretion.

Intriguingly, serum levels of $25(\mathrm{OH}) \mathrm{D} 2$ were significantly higher in both pregnancy groups relative to non-pregnant controls. The explanation for this is unclear as vitamin D2 is principally obtained from plants and mushrooms. One possibility is that enhanced circulating $25(\mathrm{OH}) \mathrm{D} 2$ is due to dietary modifications undertaken by women when they are pregnant. Furthermore, when considering 25(OH)D3 and 25(OH)D2 together, no significant difference in total vitamin D status was measured. Therefore, despite significantly lower 25(OH)D3 concentrations in those pregnant women who developed PET compared to the non-pregnant group, overall vitamin D status was not altered. This is consistent with previous data from the Osteoporotic Fractures in Men Study, which found higher 25(OH)D2 levels not to correlate with higher total $25(\mathrm{OH}) \mathrm{D}$, and that increased $25(\mathrm{OH}) \mathrm{D} 2$ concentrations were associated with lower $25(\mathrm{OH}) \mathrm{D} 3$ levels $(P<0.01)$ (52). Recent supplementation data similarly indicated that 25(OH)D2 supplementation decreased serum 25(OH)D3 levels (53). In serum, 25(OH)D2 binds to the serum DBP carrier with lower affinity, and this has been postulated as an explanation for the increased serum clearance of $25(\mathrm{OH}) \mathrm{D} 2$ relative to $25(\mathrm{OH}) \mathrm{D} 3$ (54). However, in the current study, it was noticeable that $25(\mathrm{OH}) \mathrm{D} 2$ was not quantifiable in urine samples, suggesting that renal handling of $25(\mathrm{OH}) \mathrm{D} 2$ bound to DBP is efficient enough to limit urinary excretion of $25(\mathrm{OH}) \mathrm{D} 2$. Re-absorption of 25(OH)D2 from glomerular filtrates into proximal tubules may lead to increased synthesis of $24,25(\mathrm{OH})_{2} \mathrm{D} 2$ and $1,25(\mathrm{OH})_{2} \mathrm{D} 2$, but as neither of these metabolites was measured in the current study, this remains to be confirmed.

To our knowledge, this is the first report of vitamin $\mathrm{D}$ metabolite quantification in the urine of pregnant women. The method utilised was adapted from that reported by Ogawa and coworkers who quantified $25(\mathrm{OH}) \mathrm{D} 3$ and $24,25(\mathrm{OH})_{2} \mathrm{D} 3$ in spot urine samples $(1 \mathrm{~mL})$ from healthy male subjects $(n=20)$ pre and post vitamin D supplementation (40). This method used the derivatization agent PTAD to quantify 25OHD3 and $24,25(\mathrm{OH})_{2} \mathrm{D} 3$ in a $700 \mu \mathrm{L}$ spot urine. This optimised method presents a reference range for urinary vitamin D during pregnancy, along with comparison to circulating serum levels. To our knowledge, this is the first time circulating and urinary vitamin $\mathrm{D}$ has been compared for clinical analysis, describing changes in both circulating and excreted levels of vitamin D on pregnancy outcome. This method combined with serum analysis will provide a comprehensive assessment in vitamin D metabolism in clinical conditions related to vitamin $\mathrm{D}$ deficiency. This method was capable of quantifying urinary 25OHD3 and $24,25(\mathrm{OH})_{2} \mathrm{D} 3$; however, under the current method conditions, levels of $1 \alpha, 25(\mathrm{OH})_{2} \mathrm{D} 3$ and $23,25(\mathrm{OH})_{2} \mathrm{D} 3$ could not be measured following derivatization, as these concentration were below the limits of detection. To assess the ability to quantify these analytes in urine, method development will be required on a later generation mass spectrometer that will enable reduced detection limits.

In pregnancy, urinary $24,25(\mathrm{OH})_{2} \mathrm{D} 3$ concentrations were approximately 3-fold higher than 25(OH)D3, representing the predominant excreted vitamin $\mathrm{D}$ metabolite. This was not evident in the non-pregnant group, for which urinary $25(\mathrm{OH}) \mathrm{D} 3$ and $24,25(\mathrm{OH})_{2} \mathrm{D} 3$ concentrations were comparable. Furthermore, in the healthy non-pregnant females, median urinary 25(OH)D3 concentrations were at least 2-fold higher than both pregnant groups, in particular, those who developed PET. Together, these findings are consistent with an increased role for $25(\mathrm{OH}) \mathrm{D} 3$ in pregnancy, with significantly enhanced classical and non-classical placental $1,25(\mathrm{OH})_{2} \mathrm{D} 3$ production and turnover from the 1 st trimester $(21,22)$. Reduced $25(\mathrm{OH}) \mathrm{D} 3$ excretion may also reflect increased neonatal vitamin $\mathrm{D}$ metabolism, as $25(\mathrm{OH}) \mathrm{D} 3$ readily diffuses across the placenta principally to permit later fetal bone development and growth (55). In rat models, VDR expression is demonstrated from a very early stage in fetal development (56).

Urinary 25(OH)D3 and $24,25(\mathrm{OH})_{2} \mathrm{D} 3$ were significantly correlated in both the normotensive and PET groups. This is consistent with serum 25(OH)D3 and

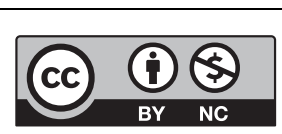

This work is licensed under a Creative Commons Attribution-NonCommercial 4.0 International License. 
$24,25(\mathrm{OH})_{2} \mathrm{D} 3$ in normal pregnancy, as evidenced here and our previous study (21). However, in normal pregnancy, serum concentrations of $25(\mathrm{OH}) \mathrm{D} 3$ and $24,25(\mathrm{OH}) 2 \mathrm{D} 3 \mathrm{did}$ not correlate with their respective urinary concentrations. Given the number of known extra-renal sites of vitamin D storage and metabolism, including the placenta, this may be anticipated. Furthermore, the kidney has the capacity to actively reabsorb vitamin D metabolites in a DBPmegalin-dependent manner (57), and this may contribute to the lack of correlation between serum and urinary vitamin D metabolites.

In the current study, urinary vitamin D metabolite analysis suggests that dysregulation of vitamin D metabolism occurs at an early stage in women who go on to develop PET. Within the context of PET, both urinary $25(\mathrm{OH}) \mathrm{D} 3$ and $24,25(\mathrm{OH})_{2} \mathrm{D} 3$ concentrations were significantly decreased compared to those who were normotensive throughout pregnancy. As discussed, alongside this increased serum concentrations of $1,25(\mathrm{OH})_{2} \mathrm{D} 3$ were measured in those with PET. This increased vitamin D metabolism to $1,25(\mathrm{OH})_{2} \mathrm{D} 3$ may arise secondary to decreased serum calcium concentrations. Within the context of PET, serum calcium concentrations are significantly reduced. A prospective study measuring the urine calcium/creatinine (Ca:Cr) clearance ratio also found women with PET excrete significantly less calcium $(n=60)$ compared to normotensive controls (51). This may account for enhanced renal 25(OH)D3 re-uptake, limiting metabolite excretion.

Urinary metabolite concentrations are susceptible to variation by factors including hydration status and overall renal function. Twenty-four-hour urine sample collections are considered the gold-standard measurement, but are cumbersome and reliant upon strict compliance. Spot samples and first morning void are widely deemed acceptable for analyte measures, provided the effect of sample dilution is quantified and appropriately adjusted $(58,59)$. At present, no consensus upon which is most appropriate adjustment technique; however, creatinine remains commonly applied. This simply calculates the ratio to creatinine concentrations and does not account for temporal variations in creatinine excretion rates (59). The potential value of a urinary marker of vitamin D status has wider clinical implications outside of pregnancy, and certainly, this method will be highly transferrable.

Moving forward, serial serum and urinary analyses at a set time-point would provide a more detailed insight into the pathogenesis of vitamin D dysregulation. It would have been interesting to include in this cohort more earlyonset PET cases $(<34$ week) $(n=1)$, which are typically

$$
\text { http://www.endocrineconnections.org }
$$

more severe (60) and women of greater ethnic diversity (61). Subgroup analysis of those women who developed PET pre-term ( $\leq 37$ week) $(n=9)$ did not reveal any significant differences with regards to the 5 major serum vitamin $\mathrm{D}$ metabolites measured (data not shown), but numbers were too small to draw any robust conclusions from this. The current study was based simply on the availability of sample material. In this setting, urinary 25(OH)D3 measurements with $n=25$ per sample group, and a difference of means of $13.86 \mathrm{ng} / \mathrm{g}$ creatinine resulted in statistical power of 0.588 at $\alpha=0.05$. To reach power of $>0.8$ would have required $n=41$ per sample group. Nevertheless, our preliminary data indicate dysregulation of vitamin D metabolism may precede clinical onset of PET. This was evident from spot urinary analyses, which offer novel insights into the underlying pathogenesis of vitamin D dysregulation in PET. From the data presented, we demonstrate that routine measurement of serum $25(\mathrm{OH}) \mathrm{D} 3$ alone provides only a limited perspective on the requirement for vitamin $\mathrm{D}$ in pregnancy. Detailed analysis of vitamin D metabolism, including renal catabolism and excretion is required.

\section{Supplementary data}

This is linked to the online version of the paper at https://doi.org/10.1530/ EC-17-0308

Declaration of interest

The authors declare that there is no conflict of interest that could be perceived as prejudicing the impartiality of the research reported.

\section{Funding}

This study was supported by funding from NIH (AR063910, M H), Wellbeing of Women (RTF401, J A T) and a Royal Society Wolfson Merit Award (WM130118, M H).

\section{Acknowledgements}

The authors would like thank Prof. Louise Kenny (University College Cork) for facilitating access to the SCOPE samples. They would also like to acknowledge help from Prof. Cedric Shackleton in establishing the urinary vitamin D metabolite analyses. The authors declare that there is no conflict of interest that could be perceived as prejudicing the impartiality of the research reported. Vitabiotics Pregnacare generously supported this work through the charity Wellbeing of Women, which independently selected the research through its AMRC accredited peer review process led by its Research Advisory Committee. Dr Tamblyn and her work were not impacted or influenced in any way by its sources of funding.

\section{References}

1 Tranquilli AL, Brown MA, Zeeman GG, Dekker G \& Sibai BM. The definition of severe and early-onset preeclampsia statements

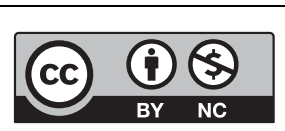

This work is licensed under a Creative Commons Attribution-NonCommercial 4.0 International License. 
from the International Society for the Study of Hypertension in Pregnancy (ISSHP). Pregnancy Hypertension 20133 44-47. (https://doi. org/10.1016/j.preghy.2012.11.001)

2 Khan KS, Wojdyla D, Say L, Gülmezoglu AM \& Van Look PFA. WHO analysis of causes of maternal death: a systematic review. Lancet 2006 367 1066-1074. (https://doi.org/10.1016/S0140-6736(06)68397-9)

3 Steegers EA, von Dadelszen P, Duvekot JJ \& Pijnenborg R. Preeclampsia. Lancet 2010376 631-644. (https://doi.org/10.1016/S01406736(10)60279-6)

4 Mol BW, Roberts CT, Thangaratinam S, Magee LA, de Groot CJ \& Hofmeyr GJ. Pre-eclampsia. Lancet 2016387 999-1011. (https://doi. org/10.1016/S0140-6736(15)00070-7)

5 Say L, Chou D, Gemmill A, Tunçalp Ö, Moller A-B, Daniels J, Gülmezoglu AM, Temmerman M \& Alkema L. Global causes of maternal death: a WHO systematic analysis. Lancet Global Health 20142 e323-e333. (https://doi.org/10.1016/S2214-109X(14)70227-X)

6 Carr A, Kershaw T, Brown H, Allen T \& Small M. Hypertensive disease in pregnancy: an examination of ethnic differences and the Hispanic paradox. Journal of Neonatal-Perinatal Medicine 20136 11-15. (https://doi.org/10.3233/NPM-1356111)

7 Fisher SJ. Why is placentation abnormal in preeclampsia? American Journal of Obstetrics and Gynecology 2015213 S115-S122. (https://doi. org/10.1016/j.ajog.2015.08.042)

8 Rădulescu C, Bacârea A, Huţanu A, Gabor R \& Dobreanu M. Placental growth factor, soluble fms-like tyrosine kinase 1, soluble endoglin, IL-6, and IL-16 as biomarkers in preeclampsia. Mediators of Inflammation 20162016 3027363. (https://doi.org/10.1155/2016/3027363)

9 Ghosh SK, Raheja S, Tuli A, Raghunandan C \& Agarwal S. Combination of uterine artery Doppler velocimetry and maternal serum placental growth factor estimation in predicting occurrence of pre-eclampsia in early second trimester pregnancy: a prospective cohort study. European Journal of Obstetrics, Gynecology, and Reproductive Biology 2012161 144-151. (https://doi.org/10.1016/j.ejogrb.2011.12.031)

$10 \mathrm{Wu}$ P, van den Berg C, Alfirevic Z, O'Brien S, Röthlisberger M, Baker PN, Kenny LC, Kublickiene K \& Duvekot JJ. Early pregnancy biomarkers in pre-eclampsia: a systematic review and meta-analysis. International Journal of Molecular Sciences 201516 23035-23056. (https://doi.org/10.3390/ijms160923035)

11 Ghosh SK, Raheja S, Tuli A, Raghunandan C \& Agarwal S. Serum placental growth factor as a predictor of early onset preeclampsia in overweight/obese pregnant women. Journal of the American Society of Hypertension 20137 137-148. (https://doi.org/10.1016/j. jash.2012.12.006)

12 Zhu XL, Wang J, Jiang RZ \& Teng YC. Pulsatility index in combination with biomarkers or mean arterial pressure for the prediction of pre-eclampsia: Systematic literature review and metaanalysis. Annals of Medicine 201547 414-422. (https://doi.org/10.310 9/07853890.2015.1059483)

13 Lafayette RA, Druzin M, Sibley R, Derby G, Malik T, Huie P, Polhemus C, Deen WM \& Myers BD. Nature of glomerular dysfunction in pre-eclampsia. Kidney International $1998 \mathbf{5 4}$ 1240-1249. (https://doi.org/10.1046/j.1523-1755.1998.00097.x)

14 Hussein W \& Lafayette RA. Renal function in normal and disordered pregnancy. Current Opinion in Nephrology and Hypertension 201423 46-53. (https://doi.org/10.1097/01.mnh.0000436545.94132.52)

15 Ayansina D, Black C, Hall SJ, Marks A, Millar C, Prescott GJ, Wilde K $\&$ Bhattacharya S. Long term effects of gestational hypertension and pre-eclampsia on kidney function: record linkage study. Pregnancy Hypertension 20166 344-349. (https://doi.org/10.1016/j. preghy.2016.08.231)

16 Garovic VD. The role of the podocyte in preeclampsia. Clinical Journal of the American Society of Nephrology 20149 1337-1340. (https://doi.org/10.2215/CJN.05940614)

17 Müller-Deile J \& Schiffer M. Preeclampsia from a renal point of view: insides into disease models, biomarkers and therapy. World Journal of Nephrology 20143 169-181. (https://doi.org/10.5527/wjn.v3.i4.169)
18 Kumar R, Tebben PJ \& Thompson JR. Vitamin D and the kidney. Archives of Biochemistry and Biophysics 2012523 77-86. (https://doi. org/10.1016/j.abb.2012.03.003)

19 Kumar R, Schaefer J, Grande JP \& Roche PC. Immunolocalization of calcitriol receptor, 24-hydroxylase cytochrome P-450, and calbindin D28k in human kidney. American Journal of Physiology 1994266 F477-F485. (https://doi.org/10.1152/ajprenal.1994.266.3.F477)

20 Turner M, Barre PE, Benjamin A, Goltzman D \& Gascon-Barre M. Does the maternal kidney contribute to the increased circulating 1,25-dihydroxyvitamin D concentrations during pregnancy? Mineral and Electrolyte Metabolism 198814 246-252.

21 Tamblyn JA, Susarla R, Jenkinson C, Jeffery LE, Ohizua O, Chun RF, Chan SY, Kilby MD \& Hewison M. Dysregulation of maternal and placental vitamin D metabolism in preeclampsia. Placenta 201750 70-77. (https://doi.org/10.1016/j.placenta.2016.12.019)

22 Evans KN, Bulmer JN, Kilby MD \& Hewison M. Vitamin D and placentaldecidual function. Journal of the Society for Gynecologic Investigation 2004 11 263-271. (https://doi.org/10.1016/j.jsgi.2004.02.002)

23 Zehnder D, Evans KN, Kilby MD, Bulmer JN, Innes BA, Stewart PM \& Hewison M. The ontogeny of 25-hydroxyvitamin $\mathrm{D}$ (3) 1alphahydroxylase expression in human placenta and decidua. American Journal of Pathology 2002161 105-114. (https://doi.org/10.1016/ S0002-9440(10)64162-4)

24 Ma R, Gu Y, Zhao S, Sun J, Groome LJ \& Wang Y. Expressions of vitamin D metabolic components VDBP, CYP2R1, CYP27B1, CYP24A1, and VDR in placentas from normal and preeclamptic pregnancies. American Journal of Physiology: Endocrinology and Metabolism 2012303 E928-E935. (https://doi.org/10.1152/ajpendo.00279.2012)

25 Tamblyn J, Hewison M, Wagner C, Bulmer J \& Kilby M. Immunological role of vitamin D at the maternal-fetal interface. Journal of Endocrinology 2015224 R107-R121. (https://doi.org/10.1530/JOE-14-0642)

26 Saraf R, Morton SM, Camargo CA Jr \& Grant CC. Global summary of maternal and newborn vitamin D status - a systematic review. Maternal and Child Nutrition 201612 647-668. (https://doi. org/10.1111/mcn.12210)

27 Hollis BW \& Wagner CL. Vitamin D deficiency during pregnancy: an ongoing epidemic. American Journal of Clinical Nutrition 200684273.

28 Bodnar LM, Catov JM, Simhan HN, Holick MF, Powers RW \& Roberts JM. Maternal vitamin D deficiency increases the risk of preeclampsia. Journal of Clinical Endocrinology and Metabolism. 2007 92 3517-3522. (https://doi.org/10.1210/jc.2007-0718)

29 Djekic-Ivankovic M, Weiler H, Jones G, Kaufmann M, Kaludjerovic J, Aleksic-Velickovic V, Mandić LM \& Glibetic M. Vitamin D status in mothers with pre-eclampsia and their infants: a case-control study from Serbia, a country without a vitamin D fortification policy. Public Health Nutrition 201620 1825-1835. (https://doi.org/10.1017/ S1368980016000409)

30 Burris HH, Rifas-Shiman SL, Kleinman K, Litonjua AA, Huh SY, RichEdwards JW, Camargo CA Jr \& Gillman MW. Vitamin D deficiency in pregnancy and gestational diabetes mellitus. American Journal of Obstetrics and Gynecology 2012207 182e1-182e8. (https://doi. org/10.1016/j.ajog.2012.05.022)

31 Bodnar LM, Catov JM, Zmuda JM, Cooper ME, Parrott MS, Roberts JM, Marazita ML \& Simhan HN. Maternal serum 25-hydroxyvitamin D concentrations are associated with small-forgestational age births in white women. Journal of Nutrition 2010140 999-1006. (https://doi.org/10.3945/jn.109.119636)

32 Wagner CL, Baggerly C, McDonnell S, Baggerly KA, French CB, Baggerly L, Hamilton SA \& Hollis BW. Post-hoc analysis of vitamin D status and reduced risk of preterm birth in two vitamin D pregnancy cohorts compared with South Carolina March of Dimes 2009-2011 rates. Journal of Steroid Biochemistry and Molecular Biology 2016155 245-251. (https://doi.org/10.1016/j.jsbmb.2015.10.022)

33 Hypponen E, Cavadino A, Williams D, Fraser A, Vereczkey A, Fraser WD, Bánhidy F, Lawlor D \& Czeizel AE. Vitamin D and pre-eclampsia: original data, systematic review and meta-analysis.

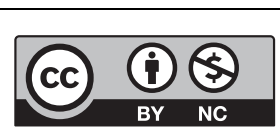

This work is licensed under a Creative Commons Attribution-NonCommercial 4.0 International License. 
Annals of Nutrition and Metabolism 201363 331-340. (https://doi. org/10.1159/000358338)

34 Harvey NC, Holroyd C, Ntani G, Javaid K, Cooper P, Moon R, Cole Z, Tinati T, Godfrey K, Dennison E, et al. Vitamin D supplementation in pregnancy: a systematic review. Health Technology Assessment 201418 1-190. (https://doi.org/10.3310/hta18450)

35 Thota C, Menon R, Fortunato SJ, Brou L, Lee JE \& Al-Hendy A. 1,25-Dihydroxyvitamin D deficiency is associated with preterm birth in African American and Caucasian women. Reproductive Sciences 201421 244-250. (https://doi.org/10.1177/1933719113493513)

36 Bennett SE, Casey C, McPeake J, McCance DR, Manderson JG \& McGinty A. 3-Epi-25 hydroxyvitamin D in pregnancy. Pregnancy Hypertension 20144 236. (https://doi.org/10.1016/j. preghy.2014.03.021)

37 Shah AD, Hsiao EC, O’Donnell B, Salmeen K, Nussbaum R, Krebs M, Baumgartner-Parzer S, Kaufmann M, Jones G, Bikle DD, et al. Maternal hypercalcemia due to failure of 1,25-dihydroxyvitamin-D3 catabolism in a patient with CYP24A1 mutations. Journal of Clinical Endocrinology and Metabolism 2015100 2832-2836. (https://doi.org/10.1210/jc.2015-1973)

38 Kenny LC, Black MA, Poston L, Taylor R, Myers JE, Baker PN, McCowan LM, Simpson NA, Dekker GA, Roberts CT, et al. Early pregnancy prediction of preeclampsia in nulliparous women, combining clinical risk and biomarkers: the Screening for Pregnancy Endpoints (SCOPE) international cohort study. Hypertension 201464 644-652. (https://doi.org/10.1161/HYPERTENSIONAHA.114.03578)

39 Jenkinson C, Taylor AE, Hassan-Smith ZK, Adams JS, Stewart PM, Hewison M \& Keevil BG. High throughput LC-MS/MS method for the simultaneous analysis of multiple vitamin $\mathrm{D}$ analytes in serum. Journal of Chromatography B 2016 1014 56-63. (https://doi. org/10.1016/j.jchromb.2016.01.049)

40 Ogawa S, Ooki S, Shinoda K \& Higashi T. Analysis of urinary vitamin $\mathrm{D}(3)$ metabolites by liquid chromatography/tandem mass spectrometry with ESI-enhancing and stable isotope-coded derivatization. Analytical and Bioanalytical Chemistry 2014406 6647-6654. (https://doi.org/10.1007/s00216-014-8095-y)

41 Peake M \& Whiting M. Measurement of serum creatinine - current status and future goals. Clinical Biochemist Reviews 200627 173-184.

42 Holick MF, Binkley NC, Bischoff-Ferrari HA, Gordon CM, Hanley DA, Heaney RP, Heaney RP, Murad MH, Weaver CM \& Endocrine Society. Evaluation, treatment, and prevention of vitamin D deficiency: an Endocrine Society Clinical Practice Guideline. Journal of Clinical Endocrinology and Metabolism 201196 1911-1930. (https://doi. org/10.1210/jc.2011-0385)

43 Kiely ME, Zhang JY, Kinsella M, Khashan AS \& Kenny LC. Vitamin D status is associated with uteroplacental dysfunction indicated by pre-eclampsia and small-for-gestational-age birth in a large prospective pregnancy cohort in Ireland with low vitamin D status. American Journal of Clinical Nutrition 2016104 354-361. (https://doi. org/10.3945/ajcn.116.130419)

44 Bodnar LM, Simhan HN, Powers RW, Frank MP, Cooperstein E \& Roberts JM. High prevalence of vitamin D insufficiency in black and white pregnant women residing in the northern United States and their neonates. Journal of Nutrition $2007137447-452$.

45 National Institute for Health and Care Excellence. Antenatal care for uncomplicated preganancies. NICE clinical guideline 62. London, UK: NICE, 2008. (available at: https://www.nice.org.uk/guidance/cg62)

46 O'Reilly-Marshall A. Antenatal Care. Nutrition in pregnancy. Dublin, Ireland: Irish College of General Practitioners, 2010. (available at: https://www.icgp.ie/assets/21/7FB21F16-19B9-E18583915661D103354F_document/DL23-28.pdf)

47 Powe CE, Seely EW, Rana S, Bhan I, Ecker J, Karumanchi SA \& Thadhani R. First trimester vitamin D, vitamin D binding protein, and subsequent preeclampsia. Hypertension 201056 758-763. (https://doi.org/10.1161/HYPERTENSIONAHA.110.158238)

48 Messerlian S, Gao X \& St-Arnaud R. The 3-epi- and 24-oxo-derivatives of 1alpha,25 dihydroxyvitamin $\mathrm{D}(3)$ stimulate transcription through the vitamin D receptor. Journal of Steroid Biochemistry and Molecular Biology 200072 29-34. (https://doi.org/10.1016/S09600760(99)00148-X)

49 Soma-Pillay P, Catherine N-P, Tolppanen H, Mebazaa A, Tolppanen H \& Mebazaa A. Physiological changes in pregnancy. Cardiovascular Journal of Africa 201627 89-94. (https://doi.org/10.5830/CVJA-2016-021)

50 Kanagal DV, Rajesh A, Rao K, Devi UH, Shetty H, Kumari S \& Shetty PK. Levels of serum calcium and magnesium in pre-eclamptic and normal pregnancy: a study from coastal India. Journal of Clinical and Diagnostic Research 20148 OC01-OC04. (https://doi. org/10.7860/JCDR/2014/8872.4537)

51 Ozcan T, Kaleli B, Ozeren M, Turan C \& Zorlu G. Urinary calcium to creatinine ratio for predicting preeclampsia. American Journal of Perinatology 199512 349-351. (https://doi. org/10.1055/s-2007-994494)

52 Swanson CM, Nielson CM, Shrestha S, Lee CG, Barrett-Connor E, Jans I, Cauley JA, Boonen S, Bouillon R, Vanderschueren D, et al. Higher $25(\mathrm{OH}) \mathrm{D}(2)$ is associated with lower $25(\mathrm{OH}) \mathrm{D}(3)$ and $1,25(\mathrm{OH})(2) \mathrm{D}(3)$. Journal of Clinical Endocrinology and Metabolism 201499 2736-2744. (https://doi.org/10.1210/jc.2014-1069)

53 Demetriou ET, Travison TG \& Holick MF. Treatment with 50,000 IU vitamin $\mathrm{D}(2)$ every other week and effect on serum 25-hydroxyvitamin $\mathrm{D}(2), 25$-hydroxyvitamin $\mathrm{D}(3)$, and total 25-hydroxyvitamin D in a clinical setting. Endocrine Practice 201218 399-402. (https://doi.org/10.4158/EP11268.OR)

54 Jones KS, Assar S, Harnpanich D, Bouillon R, Lambrechts D, Prentice A \& Schoenmakers I. 25(OH)D(2) half-life is shorter than $25(\mathrm{OH}) \mathrm{D}(3)$ half-life and is influenced by dbp concentration and genotype. Journal of Clinical Endocrinology and Metabolism 201499 3373-3381. (https://doi.org/10.1210/jc.2014-1714)

55 Nicolaidou P, Hatzistamatiou Z, Papadopoulou A, Kaleyias J, Floropoulou E, Lagona E, Tsagris V, Costalos C \& Antsaklis A. Low vitamin D status in mother-newborn pairs in Greece. Calcified Tissue International 200678 337-342. (https://doi.org/10.1007/s00223-006-0007-5)

56 Salle BL, Delvin EE, Lapillonne A, Bishop NJ \& Glorieux FH. Perinatal metabolism of vitamin D. American Journal of Clinical Nutrition 2000 71 1317s-1324s.

57 Nykjaer A, Dragun D, Walther D, Vorum H, Jacobsen C, Herz J, Melsen F, Christensen EI \& Willnow TE. An endocytic pathway essential for renal uptake and activation of the steroid 25-(OH) vitamin D3. Cell 199996 507-515. (https://doi.org/10.1016/S00928674(00)80655-8)

58 Rivera-Núñez Z, Meliker JR, Linder AM \& Nriagu JO. Reliability of spot urine samples in assessing arsenic exposure. International Journal of Hygiene and Environmental Health 2010213 259-264. (https://doi. org/10.1016/j.ijheh.2010.03.003)

59 Hidalgo AA, Deeb KK, Pike JW, Johnson CS \& Trump DL. Dexamethasone enhances 1alpha,25-dihydroxyvitamin D3 effects by increasing vitamin D receptor transcription. Journal of Biological Chemistry 2011286 36228-36237. (https://doi.org/10.1074/jbc.M111.244061)

60 Lisonkova S \& Joseph KS. Incidence of preeclampsia: risk factors and outcomes associated with early- versus late-onset disease. American Journal of Obstetrics and Gynecology 2013209 544.e1-544.e12. (https://doi.org/10.1016/j.ajog.2013.08.019)

61 Goodwin AA \& Mercer BM. Does maternal race or ethnicity affect the expression of severe preeclampsia? American Journal of Obstetrics and Gynecology 2005193 973-978. (https://doi.org/10.1016/j. ajog.2005.05.047)

Received in final form 22 November 2017

Accepted 7 December 2017

Accepted Preprint published online 7 December 2017 http://www.endocrineconnections.org https://doi.org/10.1530/EC-17-0308
() 2018 The authors Published by Bioscientifica Ltd
This work is licensed under a Creative Commons Attribution-NonCommercial 4.0 International License. 